\title{
Comments
}

\section{TAX TREATMENT OF POST-TERMINATION PERSONAL INJURY SETTLEMENTS}

\begin{abstract}
Although personal injury damages have always been excluded from the income tax, this exemption has not generally been exploited by those seeking tax loopholes. A case decided recently by the Tax Court, ${ }^{1}$ however, has created a potential for abuse in one area: the settlement of personal injury claims between a terminated employee and his former employer. This Comment discusses the problems inherent in the settlement of post-termination personal injury claims, and points out the weakness and dangers of the Tax Court's recent ruling.
\end{abstract}

\section{The Exemption of Personac Injury Damages}

Section 104(a)(2) of the Internal Revenue Code excludes from gross income "the amount of any damages received (whether by suit or agreement) on account of personal injuries or sickness." Despite the reasoning of some courts justifying the exemption of these damages froin the incoine tax because they are derived neither from labor nor from capital, ${ }^{3}$ the tax treatment of personal injury recoveries is probably based less on such legalistic arguments than on the notion that taxation of recoveries for pain and suffering would be offensive - that the victim is more properly to be pitied than taxed. ${ }^{4}$ The rule simply reflects the humane desire not to burden those already injured. ${ }^{5}$ It also reflects the practical difficulties of segregatimg the taxable and nontaxable elements of a personal injury award, ${ }^{8}$ for if the entire sum received as damages were not exempted from taxation, an allocation would have to be inade between the amount received as compensation for the actual injury suffered and the amount received in lieu of income lost on account of the injury.

The exclusion of compensatory damages from gross income has never caused a great deal of difficulty, either conceptually or ad-

1. Dudley G. Seay, 58 T.C. 32 (1972), acquiesced in, 1972 INT. Rev. Bull. No. 37 , at 5 .

2. INT. REv. CODE OF 1954, § 104(a)(2).

3. Edward H. Clark, 40 B.T.A. 333, 335 (1939).

4. Harnett, Torts and Taxes, 27 N.Y.U. L. REv. 614, 626-27 (1952).

5. Note, Taxation of Damage Recoveries from Litigation, 40 CoRNELI L.Q. 345, 346 (1955).

6. Id. 
ministratively. Nor has it been troublesome that recoveries for nonphysical personal imjuries receive the same treatment as those for physical imjuries. They, too, serve to make the plaintiff whole ${ }^{7}$ - to compensate for some wrong he has suffered. The individual who recovers for mjury to his personal reputation has not realized a taxable gain any more than the individual who collects damages for a broken leg.

Recoveries for one category of nonphysical injury, however, are treated differently. Damages received for injury to one's business reputation consistently have been treated as taxable, ${ }^{8}$ even though anounts received for injury to personal reputation have been excluded from gross incoine. When damages are recovered for an injury to one's reputation, therefore, an allocation generally must be made between amounts attributable to injuries of a personal nature and those awarded to compensate for damage to one's earning capacity. No such allocation is made with respect to damages for physical mjuries, although they too conceivably could be broken down into taxable and nontaxable components. This difference, regardless of its theoretical merit, probably can be attributed to feelings that the nonphysical injury is somehow less deserving of the generous tax treatment given recoveries for bodily harms. ${ }^{9}$ But whatever the underlying rationale, the courts and the Internal Revenue Service seem to agree that damages for injury to one's business reputation should be taxed instead of receiving the favorable treatment reserved for personal injury recoveries. ${ }^{10}$

Since, under normal circumstances, the amount of a personal injury judgment or settlement is fixed, and is not attributable to any relationship between the opposing parties other than that of tortfeasor and victim, there usually can be hittle doubt about the legitimacy of a taxpayer's claim for an exclusion under section 104(a)(2). The op-

7. Here there is only the compensation which the law sanctions as the only remedy which has thus far been devised for an injury which in its nature is wholly personal and nonpecuniary. Even to the economist, character and reputation or other strictly personal attributes are not capital or otherwise measurable in terms of wealth, notwithstanding that all will recognize them as important factors of economic success. They are not property or goods. Such compensation as general damages adds nothing to the individual, for the very concept which sanctions it prohibits that it shall include a profit. It is an attenipt to make the plaintiff whole as before the injury.

C.A. Hawkins, 6 B.T.A. 1023, 1024-25 (1927).

8. See Note, Taxation of Damage Recoveries from Litigation, supra note 5, at 346-47. See also note 51 infra.

9. One possible reason for such feelings is a belief that the nonphysical injury is simply a less serious blow to the victim. It also inay be felt that the typical injury to one's reputation is inore closely related to one's income-producing capacity than the typical physical injury.

10. See, e.g., Mason K. Knuckles, 23 CCH Tax Ct. Mem. 182 (1964), aff'd, 349 F.2d 610 (10th Cir. 1965); Nathan Agar, 19 CCH Tax Ct. Mem. 116 (1960), aff'd, 290 F.2d 283 (2d Cir. 1961). See also text accompanying notes 68-70 infra. 
portunity for a taxpayer to inflate any sum received as damages to include amounts which instead ought to be considered as income just does not arise im the usual tort case. There is, however, a situation in which the relationship between the parties does not necessarily ensure the legitimacy of payments ostensibly inade for personal injury damages: settlement between an employer and a terminated enployee for alleged ijjury to the employee's reputation.

\section{Post-Termination Personal Injury Settlements}

\section{A. A Hypothetical Case}

John Jones is an executive officer of the Acme Widget Company. His five-year contract, at a salary of $\$ 50,000$ a year, includes profitsharing provisions and other fringe benefits. After Jones has served one year in this position, the board of directors of Acne becomes dissatisfied with his performance and fires him. Jones feels that the board has acted unjustly, and heated words are exchanged.

Attorneys for Jones and Acme meet to determine how znuch pay is due him. Jones feels that he should receive $\$ 100,000$, while the company's position is that $\$ 75,000$ would be an adequate equivalent for a year's salary plus fringe benefits. In the course of negotiations, the parties realize that by allocating a portion of the settlenient figure to damages for imjury to Jones' reputation, mental and physical health, and for personal enibarrassinent, both sides can be satisfied without either having to compromise. Assuming that any amount received by Jones and included in his gross income is taxable at a rate of fifty percent, a settlement of $\$ 100,000$ would only net him $\$ 50,000$. The same net result could be achieved if he were paid $\$ 75,000-\$ 50,000$ attributable to a year's salary, with the renuaining $\$ 25,000$ allocated to damages for personal injuries. Of the salary payment, $\$ 25,000$ would remain after taxes; and the additional $\$ 25,000$ payment for personal injuries would be tax-exenpt, so his after-tax total would be the same as if he had received the full $\$ 100,000$ he thought due him. Meanwhile, the conpany could deduct the entire sum paid the employee, regardless of whether any part of it were allocated to damages for personal injuries. ${ }^{11}$ It is therefore advantageous for both parties to allocate in this manner: the employee gets the benefit of the full amount he felt he deserved, while the company pays only the lesser sum that it deemed appropriate. The ouly loss-the amount of tax that would

11. Tort payments are deductible as "ordinary and necessary" business expenses under section 162(a) of the Code, even if the tort was willful. See Helvering v. Hampton, 79 F.2d 358 (9th Cir. 1935). See also Commissioner v. Tellier, 383 U.S. 687 (1966). 
have been due on the sum attributed to damages rather than salaryis borne by the tax collector, and, therefore, the public.

The temptation for the two parties to collude in a fraudulent allocation is all the more serious because the situation leading up to the settlement lends credibility to such an allocation. There well may be events connected with the employee's discharge which could be poimted to as support for his personal injury claim. Thus, unlike the typical sum designated by the taxpayer as coming under the exemption of section 104(a)(2), payments in settlement of post-termination personal mjury claims merit close scrutiny because of the possibilities of collusion between the parties. Nevertheless, the Tax Court recently ignored the potential seriousness of this problem in Dudley G. Seay, ${ }^{12}$ a case strikingly similar to that hypothecated above.

\section{B. The Facts of SEAY}

In 1965, Dudley G. Seay was, and had been for five years, president of the Basic Products Corporation. ${ }^{13}$ Seay wished to purchase two divisions of Basic and sought the necessary financial backing. $\mathrm{He}$ reached an agreement with the Farmers Union Grain Terminal Association (GTA) under which GTA purchased the assets of the two divisions, leasing the assets of one to a company called the Froedtert Malt Corporation. ${ }^{14}$ Seay was made president of Froedtert and was given a five-year contract at $\$ 60,000$ per year plus a share of the profits. $^{15}$ His resignation as president of Basic was followed by newspaper publicity which he found somewhat enbarrassing, since it failed to imdicate that he had been given the opportunity to purchase the two divisions of Basic. ${ }^{18}$

In 1966, Seay was dismissed by the board of directors of Froedtert after a dispute with the management of GTA. The specific reason given for the termination of his employment was that, contrary to the by-laws of the company, Seay, the president, was not a director. ${ }^{17}$ Acting on the advice of counsel, Seay refused to vacate his office. Froedtert filed a complaint alleging trespass and sought an injunction to keep Seay from occupying the premises or managing the company. The filing of the complaimt was publicized in local newspapers and the Wall Street Journal. The articles referred to the complaimt, and mentioned Seay's having been replaced in 1965 as president of Basic.

12. 58 T.C. 32 (1972).

13. Id. at 33.

14. Id.

15. Id.

16. Id.

17. Id. 
Seay claimed that the publicity was a source of embarrassment and that it damaged his personal reputation. ${ }^{18}$ He instructed his attorney to file a counterclaim for damages arising from the adverse publicity and from the alleged breach of his employment contract. This claim was never even prepared, however, for a settlement was reached in only two weeks. ${ }^{19}$

Two of Seay's fellow officers at Froedtert had also been dismissed, and the settlement agreement included their claims, which were similar to those of Seay. Counsel for the company had been instructed that the total settlement should not exceed $\$ 300,000$ plus five percent of the profits, and the lump-sum agreed upon $(\$ 250,000)$ was well within this amount. $^{20}$ The settlement agreement did not allocate the sum in any way.

Seay's share of the settlement was $\$ 105,000$. Four days after the agreement was signed, his attorney prepared a letter, to be signed by the company's counsel, confirming that the settlement was made with the understanding that it consisted of one year's salary $(\$ 60,000$ for Seay) plus $\$ 45,000$ for damages caused by the newspaper publicity. ${ }^{21}$ The letter stated that this additional sum was paid " 'as compensation for such personal embarrassment, mental and physical strain and injury to health and personal reputation in the community" "as had been suffered. ${ }^{22}$

Seay reported the $\$ 60,000$ salary-equivalent, less his share of the legal fees, as ordinary income on his 1966 tax return. The Commissioner assessed a deficiency, increasing Seay's income by the $\$ 45,000$ additional payment. The question before the Tax Court was whether this amount was excludible from gross income under section 104(a)(2) as damages received on account of personal injuries. The Commissioner contended that Seay failed to prove any personal injuries for which he could have recovered damages, and that even if he had suffered such mjuries, the $\$ 45,000$ was not received in settlement of a claim based upon them. ${ }^{23}$ The court held that the $\$ 45,000$ was received for personal imjuries withm the meaning of section 104(a)(2)..$^{24}$ This

18. Id. at 34 ,

19. Id.

20. Id.

21. Id. at 35. The letter also allocated $\$ 45,000$ as damages to each of the other two terminated employees. The court found this equal allocation significant, since each of the three recipients received a different amount in salary. See id. at 38. There are no facts set forth, however, to support either an inference that the three suffered similar injuries resulting in equal damage to each, or that they had equal amounts of non-salary compensation due them from the company.

22. Id. at 35 .

23. Id. at 36 .

24. Id. at 37 . 
determination was made on the assumption that whether or not "a settlement payment is exempt from taxation depends on the nature of the claim settled and not on the validity of the claim."25

It is the application of this "nature but not validity of the claim" test to post-termination personal imjury settlements which is criticized by this Comment. As mentioned earlier, the circumstances surrounding the settlement of a post-termination personal imjury claim dictate that the facts of each case be closely scrutinized. The application of a test which fails to examine the validity of the personal injury claim can only serve to increase the already great possibility of fraudulent allocations.

\section{The Tax Treatment of Allocations}

\section{A. The Nature of the Amount Received and the Role of Conflicting Tax Interests}

The tax treatment of any sum received by a taxpayer in settlement of a legal claim is dependent upon the nature of the claim..$^{20}$ The question is often asked, "In lieu of what were the damages awarded?"27 This "nature of the claim" test is frequently invoked, for example, to determine whether amounts received by a taxpayer should be treated as ordinary income or as capital gain. ${ }^{28}$ Because of the fine line between the two-the value of a capital asset is its income-producing capacity-it is frequently necessary to determine whether the damages recovered constitute a return of capital or of lost income. Thus, a plaintiff's recovery of the value of capital assets wrongly acquired by the defendant may be treated as capital gain, while a return of rents, royalties or dividends associated with such assets will be ordimary incoine. The underlying nature of the plaintiff's claim must be determined in order to ensure the fair and proper tax treatment of the dainage payinents.

In many situations the intent of the parties to a contract or other agreement will determine the treatment of certain amounts for tax purposes. Generally, where an allocation must be made between two categories of payinents, there is a natural conflict of interests between the parties due to the differing tax consequences of the two kinds of

25. Id.

26. Spangler v. Commissioner, 323 F.2d 913, 916 (9th Cir. 1963), and cases cited therein at 916 n.4.

27. Raytheon Prod. Corp. v. Commissioner, 144 F.2d 110, 113 (1st Cir.), cert. denied, 323 U.S. 779 (1944); Estate of Mabel K. Carter, 35 T.C. 326, 332 (1960), aff'd, 298 F.2d 192 (8th Cir.), cert. denied, 370 U.S. 910 (1962).

28. See, e.g., Spangler v. Commissioner, 323 F.2d 913 (9th Cir. 1963); Estate of Mabel K. Carter, 35 T.C. 326 (1960), aff'd, 298 F.2d 192 (8th Cir.), cert. denied, 370 U.S. 910 (1962). 
payments. For example, in the case of support payments made in connection with a divorce, there may be a choice between paying a lumpsum settlement and periodic alimony payments. If one spouse pays alimony, he will be able to deduct those amounts froin his income. ${ }^{29}$ They, in turn, will be charged as income to the receiving spouse. ${ }^{30}$ On the other hand, if a lump-sum settlement is made, there will be no deduction to the paying spouse, but neither will the payment be treated as income to the receiving spouse. The conflicting tax interests of the parties choosing between these two forms of payment minimize the need to examine their agreement for collusion.

The same is true, when a business is being sold, of the allocation between a covenant not to compete and a sale of goodwill. ${ }^{31}$ The buyer may amortize any amount designated as payment for a covenant not to compete over its useful life, while money received by the seller for the covenant is treated as ordinary income. On the other hand, receipts allocated to the sale of goodwill are treated as capital gain to the seller, while the buyer gets a nondepreciable capital asset. Obviously, the informed seller, desirous of capital treatment, will want as large a sum as possible allocated to the sale of goodwill, and the taxwise buyer will want to see the greater amount attributed to a covenant not to compete. ${ }^{32}$ Assuming an arm's length agreement, these conflicting tax objectives will normally prevent any collusion resulting in fraudulent allocations. But what if the seller has huge losses in the year in which the sale takes place, so that any amount he receives as income for a covenant not to compete will be offset by his losses? The natural conflict of interests disappears in such a case, and the transaction must be carefully scrutinized to determine the true nature of the payments. ${ }^{33}$

Section 104(a)(2) codifies for personal imjury settlements the general rule that the classification of amounts received in settlement of liti-

29. See INT. REV. CODE OF 1954, § 215.

30. Id. § 71.

31. The purchase price normally exceeds the value of the tangible assets transferred, with the excess being allocated either to goodwill or to the seller's covenant not to compete. Note, Judicial Treatment of Covenants Not To Compete, 24 TAX L. REv. 513 (1969).

32. Id.

33. In the context of the typical personal minury settlement there is no allocation made, since there is only one possible characterization of the payment-personal imjury damages. The above non-tort examples are discussed to illustrate the conflict of interests that normally exists between two parties when there is an allocation made between categories of payments with different tax consequences. The subject of this Comment, the post-termination personal injury settlement, presents the uniqne situation where an allocation is made between nontaxable damages and taxable compensation payments, with no strain between the parties to ensure the honesty of the allocation. 
gation depends upon the nature and basis of the action settled. ${ }^{34}$ The probability of the taxpayer's having prevailed on the merits, had there been no settlement, is not considered. It is sufficient for exemption under section 104(a)(2) that the defendant agreed to settle the taxpayer's personal injury claim. This practice reflects the assumption that the relationship between the parties was such that the payments could be attributed only to the personal injury claim; however, the "nature of the claim" test does not necessarily foreclose an examination of the validity of the taxpayer's claim. The reason for omitting a consideration of the validity of the claim in the majority of cases is the presumption that it would not have been settled but for such validity. When the tax interests of the parties create no conflict, however, the validity of the claim settled cannot be assumed, but must instead be examined carefully. Because of the lack of strain between the parties to a post-termination personal injury settlement, the closest scrutiny must be focused on the facts of such cases.

\section{B. The Test in SEAY}

The Seay court derived its "nature but not validity of the claim" test from a 1951 Tax Court case, Tygart Valley Glass Co. ${ }^{85}$ In that case, the question was raised whether monies received by the corporate taxpayer under a settlement agreement should be treated as capital gain or as ordinary imcome. The taxpayer contended that it had recovered on a fraud claim and that the recovery should be treated as a return of capital. The Government's position, however, was that the recovery was made on a claim for the refund of rents and royalties, and that ordinary inconie treatment was proper. Each side disputed the validity of the other's characterization of the claim. There was no doubt, however, that the payments were genuinely nrade in settlement of the taxpayer's claim, whatever its true characterization. In that sense, the validity of the claim was unquestioned.

The position taken by the court was that whether or not the taxpayer might have succeeded on the nerits of either a fraud claim or a refund claim, had there been no settlement, such speculation should not enter into the determination of the underlying nature of the matter that was settled. ${ }^{36}$ The legitimacy of the taxpayer's claim against the

34. Section 104(a)(2), in excluding personal injury damages from gross income, expressly applies to "damages received (whether by suit or agreement)." INT. REv. CODE of 1954, \& 104(a)(2). This terminology is designed to cover amounts received "through prosecution of a legal suit or action based upon tort or tort type rights, or through a settlement agreement entered into in lieu of such prosecution." Treas. Reg. \& 1.104-1(c) (1970).

35. 16 T.C. 941 (1951).

36. Though both parties have argued at some length as to the validity of each claim, we consider it unnecessary to decide upon such validity, as to 
other party was not in doubt; therefore, the nature of that claim should determine the tax treatment of the amount recovered, regardless of the relative validity of the two characterizations of the claim.

The Seay court borrowed this "nature but not validity of the claim" test, ${ }^{37}$ and misapplied it to a case where the legitimacy of the taxpayer's claim could not merely be presumed. In Seay, saying that "the burden of proof does not require [the taxpayer] to show that he had a valid claim for damages"38 is tantamount to saying that a fraudulent claim will do just as well, so long as it is purportedly for personal injury damages.

The Seay court cites a number of cases holding, it asserts, that the taxpayer does not have to prove the validity of his claim. ${ }^{39}$ Not one of these cases actually supports this position. They all endorse the basic "nature of the claim" test, but none indicates that the validity of the claim settled is immaterial. Rather, they are all cases in which the validity of the taxpayer's claim could have been presumed because of the conflicting interests of the parties to the settlement. Seay itself is the only case suggesting that the validity of the settled claim need not be considered. ${ }^{40}$

By stating that the proper test is to determine the nature, but not the validity, of the claim settled, the Seay opinion creates an illusory

\footnotetext{
either, for our question is not their validity, but the nature, for tax purposes, of an amount received in settlement, which rests not upon the validity but Id. at 949. upon the nature of the matter settled.
}

37. This "nature but not validity of the claim" test is no different than that commonly used to determine whether an amount recovered by a taxpayer sliould be treated as ordinary income or as capital gam; however, the wording "nature but not validity" is inaccurate and unfortunate. The Tygart court did not intend, by the use of this phrase, to suggest that it is immaterial whether or not a claim upon which a taxpayer has allegedly recovered was valid or was inerely a shain devised for the purpose of obtaining a tax break. There is nothing in the approach taken by Tygart whicl indicates that, in determining the "nature" of the claim, this question (which is the questiou of validity) should not be considered in an appropriate case. The language "nature but not validity" was employed only to einphasize that the taxpayer's own characterization of his claim (or the characterization of the Government) is of little significance in the overall consideration of the true nature of the amount received in settlennent. In Seay, however, the phrase borrowed from Tygart is used to avoid totally any examination of the validity of the taxpayer's personal injury claim. As a result, the taxpayer's characterization of his settled claim as one in tort becomes the controlling factor, contrary to the teaching of Tygart.

38. 58 T.C. at 36.

39. Spangler v. Commissioner, 323 F.2d 913 (9th Cir. 1963), aff'g 20 CCH Tax Ct. Mem. 1783 (1961); Carter's Estate v. Commissioner, 298 F.2d 192 (8th Cir. 1962), aff'g 35 T.C. 326 (1960), cert. denied, 370 U.S. 910 (1962); Sanders v. Coinmissioner, 225 F.2d 629 (10th Cir. 1955), cert. denied, 350 U.S. 967 (1956); Morse v. United States, 371 F.2d 474 (Ct. Cl. 1967); Chalmers Cullins, 24 T.C. 322 (1955).

40. Even in Tygart Valley Glass $C o$., the court felt it "must consider the payment of the amount here in question in the light of all the circumstances and determine the motive behind the payment." 16 T.C. at 951 (emphasis added). 
distinction, for the two tests are not mutually exclusive. An examination of either the nature or validity of a claim does not preclude the consideration of the other. In Seay, the unusual lack of strain between the parties to the agreement should have dictated that the validity of the claim be examined. The true nature of the amount received in settlement cannot be determined in such a case without looking into the question of validity.

\section{The Precedents of Seay}

\section{A. The Early History}

Before Seay, there were three Tax Court decisions involving the tax treatment of sums received in settlement of post-termination personal injury claims. ${ }^{41}$ The earliest of these cases was C. A. Hawkins. ${ }^{42}$ Hawkins had been engaged in corporate management when he was fired by the directors of the corporation, some of whom inade defamatory statements accusing him of having misused corporate funds. His ensuing claim against the company and several of its officers was settled, and the question before the court was whether the damages he received in settlement of his defamation claim were taxable as incoine. ${ }^{43}$

There was no question about either the nature or validity of Hawkins' claim; the only question was whether damages received for the personal imjury suffered were taxable. The court held that damages recovered by the taxpayer for injury to his personal reputation and health as a result of the defamatory statements were not income. ${ }^{44}$ The foundation laid by Hawkins for the exclusion froin incoine of damages recovered for mijury to personal reputation has remained intact since 1927.

\section{B. The Payor's Intent Test}

A more recent case than Hawkins is Nathan Agar. ${ }^{45}$ Agar entered into a five-year employment contract as treasurer and director of a corporation which had previously retained his services as an accountant for many years. ${ }^{46}$ After little more than a year, relations be-

41. C.A. Hawkins, 6 B.T.A. 1023 (1927); Nathan Agar, 19 CCH Tax Ct. Mem. 116 (1960), aff'd, 290 F.2d 283 (2d Cir. 1961); Mason K. Knuckles, 23 CCH Tax Ct. Mem. 182 (1964), aff'd, 349 F.2d 610 (10th Cir. 1965).

42. 6 B.T.A. 1023 (1927).

43. Id.

44. Id. at $1024-25$.

45. Nathan Agar, 19 CCH Tax Ct. Mem. 116 (1960), aff'd, 290 F.2d 283 (2d Cir. 1961).

46. $19 \mathrm{CCH}$ Tax Ct. Mem. at 116. His contract provided for a fixed annual salary, payable in weekly installments, and imcluded a "percentage compensation" profitsharing provision. In the event his contract was ternninated by the company before its expiration (except in the case of removal for cause), Agar was to receive both salary and 
tween Agar and the other members of management had deteriorated and he resigned. He then informed the company that he intended to sue for imjuries resulting from ill treatment by company personnel. ${ }^{47}$ A settlement was reached on the same day. The company agreed to make three annual payments totalling $\$ 45,000$, to "cover all claims of any kind and character" that Agar may have had. ${ }^{48}$ The only issue before the Tax Court was whether these amounts were taxable.

Relying on Hawkins, Agar argued that the payments constituted compensatory damages received in settlement of his claims agamst the company for mjury to his personal reputation and health, and thus should be excluded from taxable imcome. ${ }^{49}$ The court rejected this contention, holding that even if it were assumed that the payments were made in settlement of Agar's proposed suit, the imjuries of which he complained were to his business reputation. ${ }^{\text {.0 }}$ Thus, any recovery would be taxable as ordimary income. ${ }^{51}$

The court also found that Agar had not proven that the payments were actually made in settlement of his proposed suit, but that they were in the nature of severance pay or extra compensation. ${ }^{\mathbf{2}}$ The intention with which the settlement was made by the companynot Agar's bona fide behief in the validity of his personal injury claimwas held to control the tax treatment of the payments. ${ }^{53}$ The court thus determined the taxability of these amounts not only by looking at the nature of Agar's claim-deciding that it was actually inade for injuries to his business reputation-but, more importantly, by examining the intention with which the claim was settled and paid by the employer. In its inquiry into the controlling reasons behind the payments, the court stated: "[W] hile we might be persuaded to say that petitioner, in good faith, considered he had a valid claim . . . we cannot agree that this also represented [the company's] understanding of the matter."54 The court of appeals affirmed on the basis of the holding that the

"percentage compensation" in proration of the partial annual period served. The contract also provided a sum as full liquidated damages, depending upon the year in which the termination occurred. Id. at 117.

47. Id.

48. Id. at 118.

49. Id. at 119.

50. Id.

51. Thus, the damages alleged to have been paid would not fall within the exemption froin tax afforded payments for injuries to personal reputation. Rather, they would more properly be characterized as payinents made ... as compensation for past or future income which may have been or might be lost....

Id. See also note 8 supra.

52. $19 \mathrm{CCH}$ Tax Ct. Mem. at 120 .

53. Id.

54. Id. 
settlement was in the nature of severance pay, ${ }^{55}$ and not on the alternative holding that the gravamen of any claim settled was injury to business, rather than personal, reputation.

Seay states that the Agar court did not evaluate the validity of the claim, but instead attempted to determine the actual reason for the making of the settlement payment. ${ }^{56}$ Thus Seay takes the view that an examination of the payor's intent does not, or should not, involve any consideration of the validity of the claim. By completely segregating the question of validity from the general test applied to determine the nature of the amount received, Seay ignores the fact that this ultimate determination cannot be made unless the validity of the claim, as well as all other relevant factors, is considered. The test set forth in Agar, and endorsed by Seay-that the payor's intention controls the tax treatment of the payments ${ }^{57}$ - can be viewed as merely a determination whether the payments were actually made in settlement of the personal injury claim (in which case, the claim has been presumed or proven to be valid), or whether they were made for some other reason (in which case it is likely that the claim has been found not to be valid).

The Seay court seems to have been under the impression that it had to choose between two distinct tests: examining either the nature or the validity of the taxpayer's claim. But the two tests are neither exclusive nor distinct; in fact, the nature of a claim might be thought of as including some measure of its validity. Otherwise, an examination of the nature of a claim would reveal little more than the taxpayer's own characterization of it. This is the fallacy of the Seay test.

\section{Toward Consideration of Validity}

Mason K. Knuckles, ${ }^{58}$ decided four years after $A g a r$, was also relied upon by Seay. Knuckles had been employed as an executive officer of an insurance company. He was dismissed by the company's board of directors, who "believed that he had so mismanaged the company's affairs that its continued existence was imperiled." $" 50$ The board action to terminate Knuckles' employinent was a last resort, after the failure of a strategy adopted to bring about his voluntary resignation by way of threats. Knuckles brought suit against the company for breach of his einployment contract. ${ }^{80}$ Some months later, after the

55. 290 F.2d at 284.

56. 58 T.C. at 37.

57. $19 \mathrm{CCH}$ Tax Ct. Mem. at 120; 58 T.C. at 37-38.

58. Mason K. Knuckles, 23 CCH Tax Ct. Mem. 182 (1964), aff'd, 349 F.2d 610 (10th Cir. 1965).

59. $23 \mathrm{CCH}$ Tax Ct. Mem. at 182.

60. Id. at 183 . 
dollar amount of an out-of-court settlement already had been agreed upon, Knuckles' attorney proposed for the first time that the settlement be made on the basis of a personal injury claim, giving as one reason for this change in theory of recovery the resulting tax advantage to his client. $^{{ }^{11}}$ At no time, however, did the company confess any liability upon these grounds, and it refused to make any allocation solely to benefit Knuckles.

The ultimate finding of the Tax Court was that the settlement payments represented, in part, coinpensation due under the employment contract and, in part, damages for injury to busmess reputation. ${ }^{62}$ Knuckles had contended that the entire amount received was in compensation for damages to his health and personal reputation, but the court found that he had failed to sustam the burden of proving that he had actually suffered the alleged personal injuries.

He has not produced evidence from which we may do more than merely conjecture whether he had actually suffered the injury he complains of. The touchstone of his evidence is the form of action he had instituted and which was dismissed on settlement of his claim ... . We find this action to be of little help in our decision for it seems clear to us that its final theory of tort for personal imjury was motivated, not by actual actionable personal injury to petitioner, but rather by the tax advantage resulting to him for settlement on that ground. ${ }^{.3}$

The above passage indicates that the Tax Court based its decision upon a determination of the invalidity of Knuckles' personal imjury claim. Seay, however, expressly states that the Knuckles court did not evaluate the validity of the claim, ${ }^{64}$ suggesting instead that Knuckles lends support to the "nature but not validity of the claim" test. Yet Knuckles simply followed the payor's intent doctrine of Agar, developing it one step further toward the consideration of validity-a lesson the Seay court failed to learn. Seay distinguishes Knuckles because of its finding that the taxpayer's tort claim was merely an afterthought based on the tax consequences; ${ }^{65}$ but the same finding could not have been reached in Seay because the court there refused even to consider the question of validity.

\section{The Weakness AND Dangers of Seay}

The facts of Seay suggest that, had there been an exammation of the validity of the taxpayer's personal injury claim, the case might
61. Id.
62. Id. at 184.
63. Id.
64. 58 T.C. at 37.
65. Id. at 38 . 
have been decided differently. Although Seay had a five-year renewable contract with profit-sharing provisions, he settled for only one year's salary-equivalent. ${ }^{66}$ It is also significant that Seay and his two associates settled for a lump-sum of only $\$ 250,000$, when the company was willing to pay at least $\$ 300,000$ plus five percent of the profits. ${ }^{67}$ This evidence would certainly have supported a finding that Seay accepted a smaller amount than he otherwise might have received in return for the company's agreement to go along with his allocating a sizeable portion of the sum to nontaxable personal injury damages.

It should also be noted that Seay deducted his entire share of the legal fees for the settlement against his salary, instead of allocating a portion to his personal mjury claim. ${ }^{68}$ Amounts spent in the recovery of coinpensation due or of damages for imjury to business reputation are deductible under section $212(1)$ of the Internal Revenue Code, ${ }^{00}$ but legal fees for the recovery of personal injury dannages are not. ${ }^{70}$ Although Seay's failure to allocate any of the settlement expenses to his personal injury recovery might have been considered evidence of his true opinion of the nature of the amounts he received, the opinion fails even to discuss this matter.

Both Knuckles and Agar are distinguished by the Seay court because in neither of those cases did the company acquiesce in the allocation to personal injury dannages. ${ }^{71}$ The court of appeals had stated in Knuckles that the inost important fact in determining whether payments were received on account of personal injuries, in the absence of an express personal imjury settlement agreenent, is the intent of the company in inaking the payments. ${ }^{72}$ In Seay, there was no such express settlement agreement. The court, however, rehes upon the testimony of the attorney for the company that Seay's personal injury claim was a part of the settlement negotiations. ${ }^{73}$ But, with the lack of conflicting interests betwcen the parties to the settlement, and the obvious benefit

66. Of the $\$ 105,000$ received in settlement by Seay, $\$ 60,000$ was allocated to one year's salary-equivalent, while the $\$ 45,000$ additional payment was allocated to damages for his personal injury claim. Id. at 34-35.

67. Id. at 34 .

68. Id. at 35 .

69. INT. Rev. CODE OF 1954, § 212(1).

70. Joseph D. Murphy, 48 T.C. 569 (1967) (even if the injury occurred in the course of a trade or business); Paul Draper, 26 T.C. 201, 204 (1956); Robert Edward Kleinschmidt, 12 T.C. 921, 924 (1949); Rev. Rul. 418, 1958-2 CuM. BuLL. 18 (if, however, some portion of the recovery is for exemplary damages, which are taxable, a like portion of the total amount of legal fees may be deducted).

71. See 58 T.C. at 38.

72. 349 F.2d at 613.

73. 58 T.C. at 38 . After the settlement agreement had been made, a letter was drawn up allocating the payment, but this letter was not part of the original agreement. See text accompanying notes 20-22 supra. 
to the company in agreeing to the allocation to personal injury damages, that testimony should not be given such unquestioned acceptance.

In examining the payor's intent, a court should look beyond the outward characterization of the nature of the payments. In any situation where some amount is owed an einployee under his contract, but the exact amount is undetermined, the einployer's obvious intention is to settle the employee's claims for as small a sum as possible. A court should recognize that this goal may be achieved most easily by allocating a portion of the settlement to damages for supposed injuries to the employee's reputation and health, and the facts of such a case should be examined with care to establish the legitimacy of the employee's personal injury claim. In both Agar and Knuckles, the testimony of the taxpayer was given little weight because of his interest in the outcoine of the case. The testimony of another interested party should have been considered with equal skepticisin in Seay.

Knuckles and Agar are also distinguished by Seay because, in the two prior cases, it was found that the gravamen of any imjury actually suffered by the taxpayer was to his business reputation, a possibility not even discussed in the Seay opinion. Instead, the court accepts the taxpayer's characterization of his claim as personal. If any real injury to Seay's reputation resulted from the events surrounding his dismissal, it is difficult to believe that some portion of the damage was not to his business reputation, although the court's findings of fact ${ }^{74}$ reveal no evidence that the taxpayer's reputation suffered damage of any sort. A similar lack of evidence had proved fatal to the arguments of Messrs. Agar and Knuckles.

There likewise appears to have been no evidence supporting Seay's claim that both his physical and inental health suffered as a result of his dismissal. In Knuckles, the taxpayer's failure to prove that he had suffered some injury to his health led the court to conclude that his claim was not valid; ${ }^{75}$ in Agar, the court ruled against the taxpayer even though the deterioration of his health had been estabhished. ${ }^{78}$ The Seay court, however, does not even discuss this crucial element of the taxpayer's claim, but simiply concludes that "Mr. Seay believed that the publicity concerning his dismissal from employment was a source of personal embarrassment and damaging to his personal reputation, and we have no reason to doubt the bona fides of this belief." 77

74. 58 T.C. at $32-35$.

75. See $23 \mathrm{CCH}$ Tax Ct. Mem. at 185 and text accompanying notes 62-63, supra.

76. $19 \mathrm{CCH}$ Tax Ct. Mem. at 117.

77. 58 T.C. at 37. 
In every case before the Tax Court, the burden of proof is on the taxpayer to establish by a preponderance of the evidence that the proposed deficiency is incorrect. ${ }^{78}$ In Seay, this burden appears to be shockingly light, for the court agrees with the taxpayer's contention "that the burden of proof does not require him, to show that he liad a valid claim for damages." A letter written by counsel for the taxpayer and signed by the company's negotiator seems to be sufficient to convince the court of the bona fides of the taxpayer's claim and support the allocation to personal injury damages. Yet when both parties to the settlement liave an interest in an allocation to personal injury damages, a better rule would require nore than just their testimony to carry the burden of proving the nature of the settleinent payment without some minimal inquiry into the validity of the personal injury claim.

The tax treatment of certain types of recoveries may be subject to the influence of the informed practitioner. ${ }^{80}$ It is likely that Seay succeeded where his predecessors Knuckles and Agar failed because he allocated a substantial part of his settlement recovery to a salary-equivalent. It would not be the least bit difficult, lrowever, to create an even more favorable fact situation than Seay in order to support a purely fictional personal injury claim. For example, a suit for defamation could actually be filed against the employer, and the settlennent agreement could expressly provide that a portion of the sum agreed upon has been allocated to damages for personal injuries. Part of this amount could even be allocated to damages for injuries to business reputation. Some portion of the legal fees for the settleinent could be attributed to the personal injury claim, and therefore not deducted. The employee could expressly release the company from any further liability for the alleged injuries suffered to health and reputation. An attempt could also be made to introduce evidence tending to support the personal injury claims. Any or all of these steps could be taken by a taxpayer to buttress a phony allocation against attack by the Internal Revenue Service and the courts. A stronger set of facts than that in Seay could easily be presented, and if the approach of that case were followed, the floodgates would be opened to fraudulent allocations.

In view of the possibilities it presents for abuse of section 104(a) (2), Seay should be disapproved or overruled. At the very least, it should be read narrowly to hold only that the taxpayer in that particu-

78. TAx CT. RULe 32. See alsa Efrain T. Suarez, 58 T.C. 792,818 (1972) (concurring opinion, Tannenwald, J.); Burka v. Commissioner, 179 F.2d 483 (4th Cir. 1950).

79. 58 T.C. at 36. 345.

80. See Note, Taxation of Damage Recoveries from Litigation, supra noto 5, at 
lar case had shown that the payment in question was made on account of personal injuries. Certainly, Seay should not be followed with respect to the application of the "nature but not validity of the claim" test. The weakness of the Seay decision suggests that the outcome of that case might have been different had the proper test been applied. However, the danger of Seay lies not in the outcome of one particular case, but in the possible precedent for future cases, in which the Seay approach, if followed, ${ }^{81}$ could encourage schemes of tax avoidance and lead to capricious results.

Randall Barkan

81. Despite the many flaws in the Seay decision, the Commissioner has acquiesced. 1972 INT. Rev. Bull. No. 37, at 5. 